\title{
サービスの組合せに着目した複合サービス施設の最適配置 OPTIMAL CONFIGURATION OF MULTIPLE SERVICE FACILITIES AND ITS DEPENDENCE ON THE CONBINATION OF PROVIDING SERVICES
}

\author{
鈴木 勉* \\ Tsutomu SUZUKI
}

\begin{abstract}
This article formulates an optimal location problem for multiple service facilities which provide with some part of all the services. Two facilities which provide with high degree overlapping services have mutually expulsive relation each other. However, the relation shifts to mutually complement as the services provided by the facilities diversify and the degree of overlapping facility function decreases. It is found that the balanced condition of the two brings about non-uniform optimal configuration of facilities generally. It is notable that the high degree overlapping facilities should be located so that the configuration has a vibrated systematic pattern.
\end{abstract}

Keywords: multiple service facilities, facility location, Voronoi diagram, travel distance 複合施設, 施設配置, ボロノイ図, 移動距離

1.はじめに

近年, 地域施設における複合化や多機能化の動きが盛んである. 例えば，小中学校等の学校教育施設と公民館，図書館等の社会教育 施設を同一建物として設置するコミュニティスクールの例や，保䏍 園や幼稚園, 小学校に高龄者施設を隣接させ，世代間交流を促進し ようとする例など，管轄官庁の垣根を越える積極的試みも見られる ようになってきている．公立小中学校の空き教空を利用して，デイ サービスセンターや学童保育所とするケースも現れているが, これ も異なる機能を持つ施設の複合化と見なすことができる．また，立． 地問題の緩和策として，廃棄物焼却場の余熱を利用して温水プール 等を併設する事例も増加してきているが，これも複合化の範疇でと らえることができよう。

このような複数種の施設の空間的統合だけではなく, サービス水 準の向上を目的とした単一施設の多機能化によって, 同種の施設で もそのサービス内容が施設毎に個性化し，それによって施設間に役 割分担が現れる例も見られる．分散配置したそれぞれの図書館がカ バーする分野を差別化し, 図書購入の重複率をさけながら, 蔵書検 索・電子図書館などのオンライン化の充実により，相互連携によっ て他図書館の図書利用も可能にする試みがされている. 施設の提供
するサービスの多機能化が進むということは，それらのサービスを 細分化して見れば，施設間のサービスに差が生じ，同種の施設でも 相異なる多様なサービスが複合化していると解积することができる. このような地域施設の複合化の理由としては，地方部においては， 自治体の財政力の弱さという背景から, 公共用地の有効利用や管理 運営の合理化による経費節隇を目的として行われている，自治体が 単独で公共施設整備を行うことが困難な場合もあり，広域市町村が 複合施設を共有するケースも見られる。一方，大都市都心部では， 高地価による公共用地難を背景として, 土地・空間の高度利用を進 めることを目的として行われている場合が多く見られる：しかし， コミュニティスクールの考え方のように機能上の相乗効果を期待す るという積極的理由から複合化が行われる場合もある。また，公共 施設ではないが，全国各地で見られる郊外部における大規模商業コ ンプレックスも，商業施設の複合化したものと見なすことができる.

このように地域施設が複合サービスを提供する場合, 施設の最適 配置はどのようになるであろうか. 本論文では, 以下, 配置の評価 指標として, 施設までの棇移動距離あるいは平均移動距離の最小化 するという Weber 型の問題を対象とする. Weber 型の最適施設配置 に関する研究の中で複数のサービスを扱ったものとしては，提供サ 
ービスに階層構造を持つ施設の最適配置を論じた研究がある（鈴木 (1990), Okabe et al. (1997)). これらの研究では, 下位の施設のサー ビスが上位の施設でも提供されるという包含関係の仮定に基ついて いる.しかしこの階層構造を持つ施設は複合サービス施設の特殊 ケースと考えられる，施設間に包含関係が成立せず，施設 A でしか 提供されないサービスもあれば，施設 Bでしか提供されないサービ スもあるといった場合がより一般的である.岸本(2000)はこのような 多層的な構造を持った施設群の最適配置を求める手法を開発し，複 合施設や迷惑施設と複合させた場合の最適配置などを議論している. 2 つの施設を取り上げたとき，一方の施設の提供するサービスの 内，他方の施設でも提供しているサービスの割合を重複度と呼ぶこ とにする．このとき，Weber 型の施設配置では，提供するサービス の内容の重複度が大きい施設同士は，相互排斥の関係にある．すな わち，お互いに離れて立地しようとする排斥の力が働く。しかし， 施設の提供するサービスが多様化し，施設機能の重複度が減少する につれ，施設間の関係が相互補完に移行する，この場合，お互いが 近接して立地してもよい状況となる。このように，複合化した施設 に対しては，近隣住区論のような生活圈のレベル毎に施設を配置す るというような古典的な配置パターンは必ずしも成立せず，上述の 排斥と近接のバランスが最終的にもたらす適正な配置パターンを明 らかにしておく必要がある.

そこで本研究は，複数のサービスが䇥間的に結合した複合サービ ス施設の最適配置を求め, サービスの組合せが最適配置にどのよう な影䇺を与えるかを明らかにすることを目的とする．複合化のパ夕 ーンは多数の組合せが考えられるが，本研究ではその中でどのよう な複合化が望ましいかという問題は扱わず，あらかじめ複合化する ことが与えられている施設群の最適配置パターンがどのようになる かを明らかにすることを主眼とする。

続く 2 章では，本論文で対象とする複合サービス施設の定義を行 い，その最適配置問題を定式化する，3章では，最も単純な線分都 市での解析解を導出し，解の基本的特性を明確にする．そして 4 章 では, 都市平面上での問題を非線形計画問題として解く解法を概説 し，施設数が少ない場合と多い場合について計算例を示すことによ り，複合サービス施設の最適配置パターンの特性と,サービスの組 合せとの関係について論じる，最後に 5 章で本論文の結論と課題を まとめる.

\section{2. 複合サービス施設の最適配置問題の定式化}

（1）複合施設の多義性と本論文での定義

施設の複合化とは，どのように定義されるであろうか．屋影・谷 ロ・山口(1993)は, 生涯学習化社会に向けた学習基盤整備の具現化と して文教施設 (学校) と地域施設の複合化を取り上げているが，こ の中で複合の多義性を指摘している，すなわち，複合とは元来「2 種以上のものが合わさってーつとなること」,つまり集合体であるが， 施設における複合の意味としては，空間的結合の形態，管理運営の 方法, 所有関倸, 機能・活動の連携状況等により様々な解釈があり 得るため，狭義には同一の建物や敷地内に複数種の施設が同居する という空間的結合の状態を指すが，広義には建物や敷地が分離して いても相互利用や共同事業を行うなどの機能的連携を有すればよい とする場合もあるとしている.こうした整理をした上で，屋影他は，
「複合建築」という語が一般に機能的連携を条件としない空間的結 合を意味することを指摘し, 論文での定義として, 機能的連携の有 無を問わず同一建物あるいは同一敷地内に複数の用途や機能を持た せた施設（空間複合）を意味することとしている。

一方, 大内・高倉・横塚(1994)は, 救急医療というサービスが, ド クターカー等の救急施設 (あるいは救急車の配備される消防施設) と，救急病院等の医療施設の連携で成立していることに着目し，こ れらを複合施設と捉えた上で双方の施設の適正配置を論じている. この場合の複合化とは，地域内においてあるサービスの実現に複数 用途の施設群が相互補完を行うことを意味しており，上の整理に依 れば，機能的連携を有すること（機能複合）を意味している。

さらに，病院と調剂薬局のように，上述のようなサービスの供給 側での複合は見られなくても，需要側で同時に利用することの多い 施設の組合せもあり，利用者が同時利用するような一連の施設（利 用複合）も広義の複合施設と位置づけることができる．

このように，複合施設には様々な定義があり得る（図1）が, 本 論文では最初に挙げた空間複合の意味での複合施設を対象とするこ ととし，一施設がその場所で複数のサービスを提供することを明確 に表すために，以降，「複合サービス施設」と呼ぶ．本論文では，複 合サービス施設の最適配置が複合化されていない場合とどのように 異なるかを明らかにすることを目的とする.

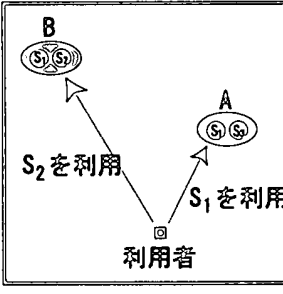

空間唖合

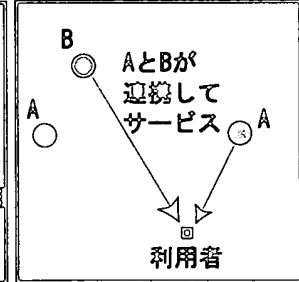

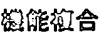

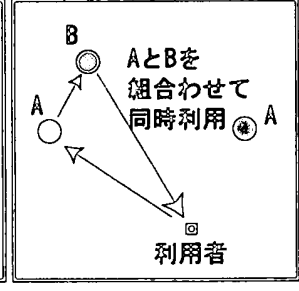

椡用縕合
图 1 褀合施設の穎型

（2）複合サービス施設のサービスの組合せ

施設の提供するサービスの組合せ方は，施設数やサービスの種類 数が多くなるほどネズミ算的に増加するが，本論文では複合化の影 響のみを抽出するために，サービスや施設は全て対等であるとする。 すなわち、サービスに優劣がある場合は，より重要なサービスを持 つ施設ほど最適性が優先されることになるし，また，施設間に提供

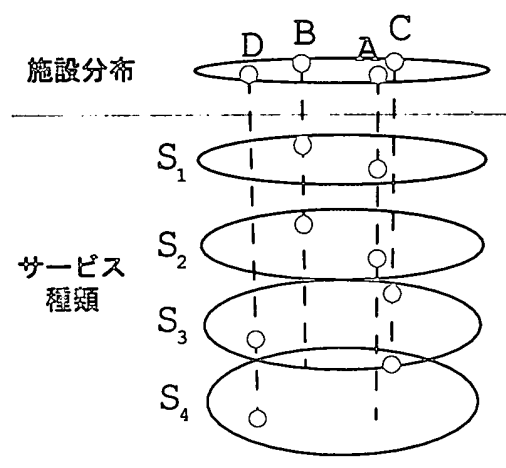

$(\theta, 2) a$

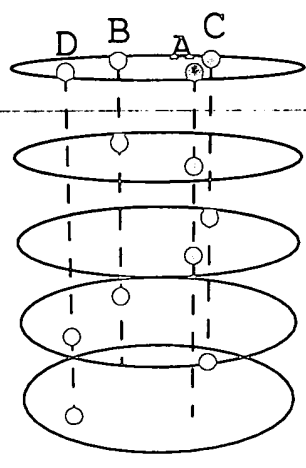

$(8,2) b$
图 2 複合サービス施設におけるサービスの組合せ の例 $(n=4, k=2)$ 


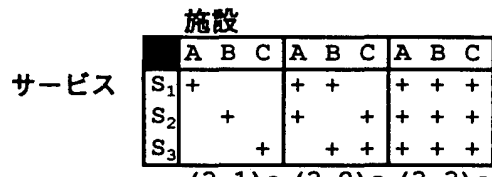

+：施設がそのサービスを提供

$(n, k): n$ 相の施設が $n$ 程のサービスのうち $k$ 程をサービスするケース

(各サービスは $k$ 程の施設により提供される)

$(3,1)$ a $(3,2)$ a $(3,3) a$

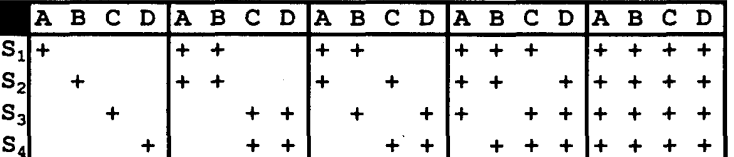

$(4,1) \mathrm{a} \quad(4,2) \mathrm{a} \quad(4,2) \mathrm{b} \quad(4,3) \mathrm{a} \quad(4,4) \mathrm{a}$

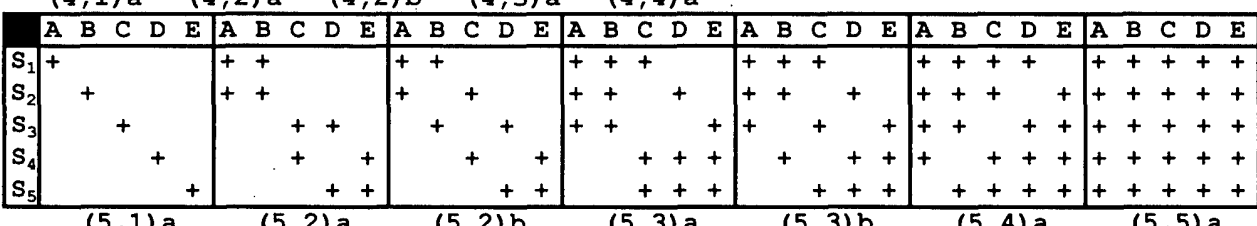

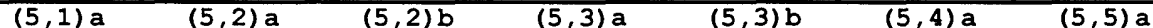

\begin{tabular}{|llllll|llllll|llllll|llllll|llllll|llllll|llllll}
\hline A & B & $C$ & $D$ & $E$ & $E$ & $A$ & $B$ & $C$ & $D$ & $E$ & $F$ & $A$ & $B$ & $C$ & $D$ & $E$ & $F$ & $A$ & $B$ & $C$ & $D$ & $E$ & $F$ & $A$ & $B$ & $C$ & $D$ & $E$ & $F$ & $A$ & $B$ & $C$ & $D$ & $E$ & $F$ & $A$ & $B$ & $C$ & $D$ & $E$ & $F$ \\
\hline
\end{tabular}
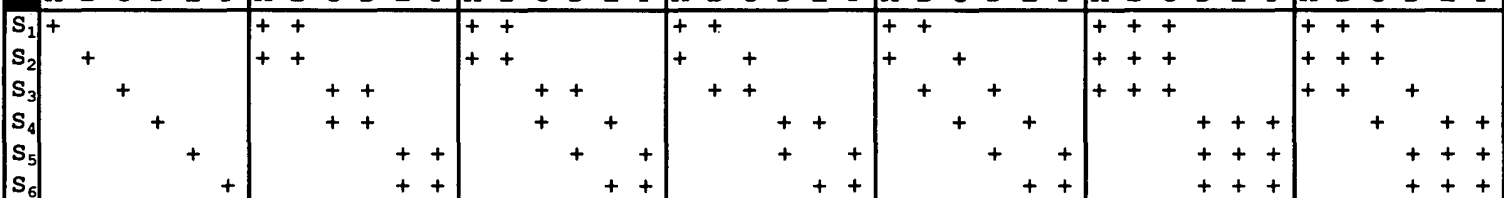

$(6,1) a \quad(6,2) a$

$(6,2) b$

$(6,2) c$

$(6,2) \mathrm{d}$

$(6,3) a$

$(6,3) \mathrm{b}$

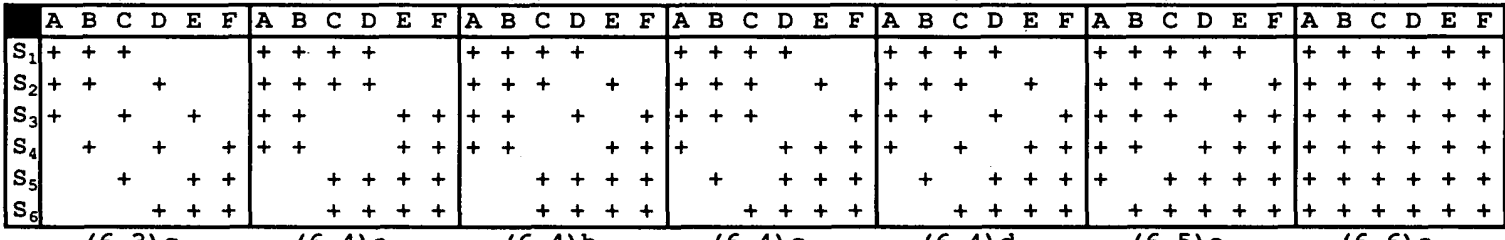

$(6,3) \mathrm{c}$

$(6,4) a$

$(6,4) \mathrm{b}$

$(6,4) c$

$(6,4) d$

$(6,6) a$

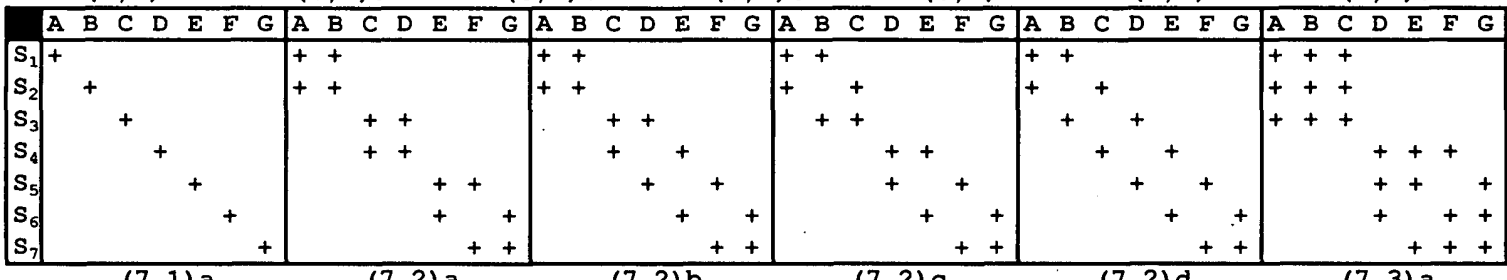

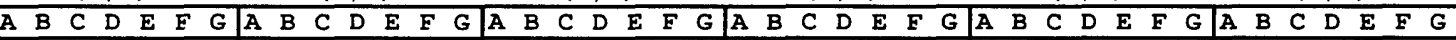

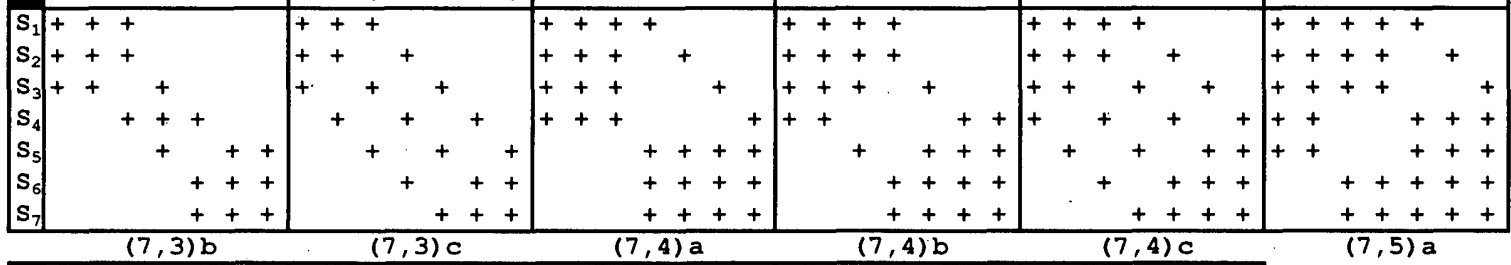

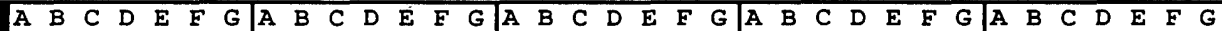

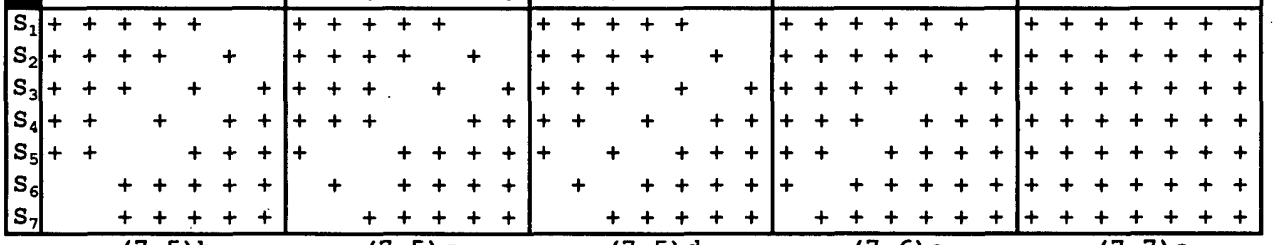

$(7,5) \mathrm{b}$

$(7,5) c$

$(7,5) d$

$(7,6) a$

$(7,7) a$

図3 施設種数・サービス種数別のサービスの組合せパターン

するサービス数に差がある場合は，その数の多い施設ほど優先され ることになる。このような場合，得られた最適配置が複合化による ものなのか，サービスや施設の優劣に起因するものなのか判断がで きない，そこで本論文では，複合化することが決まっているときに 複合化が配置に与える影響を明らかにするために，複合サービス施 設が提供するサービスは $\mathrm{S}_{1}, \mathrm{~S}_{2}, \ldots, \mathrm{S}_{n}$ の $n$ 種類があるとし，それらの
間には優劣関係がないものとする．施設はそれぞれこれらの内の一 部のサービスを提供するものとする，サービスと施設の対応関係に ついても一般には無数に考えられるが，ここでは施設も $n$ 種類ある とし，各施設はどれも $n$ 種類の中から $k$ 種類 $(1 \leq k \leq n)$ のサービスを 提供し，各サービスも $k$ 種の施設により提供されるものとする.

例えば, $n=4, k=2$ の場合, $\mathrm{A} \sim \mathrm{D}$ の 4 種の各施設はそれぞれ 2 種の 
a

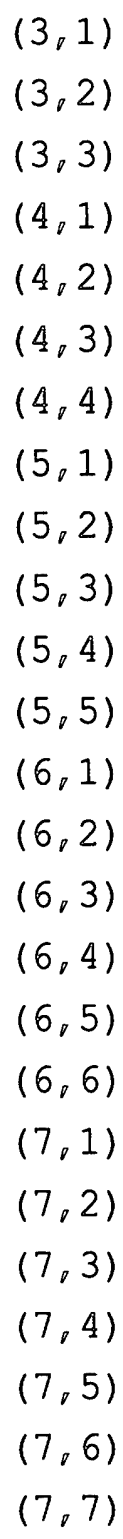

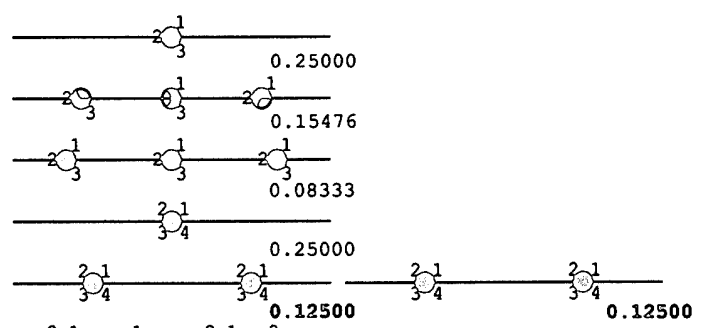

C

d

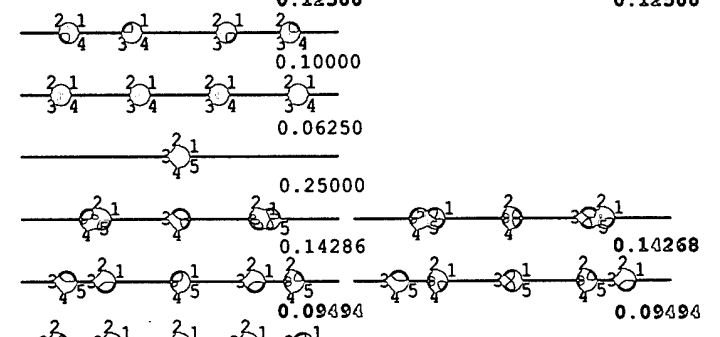

3 国 新字はその施設が缇绕する 56 ஆーピス蹓頻を示す

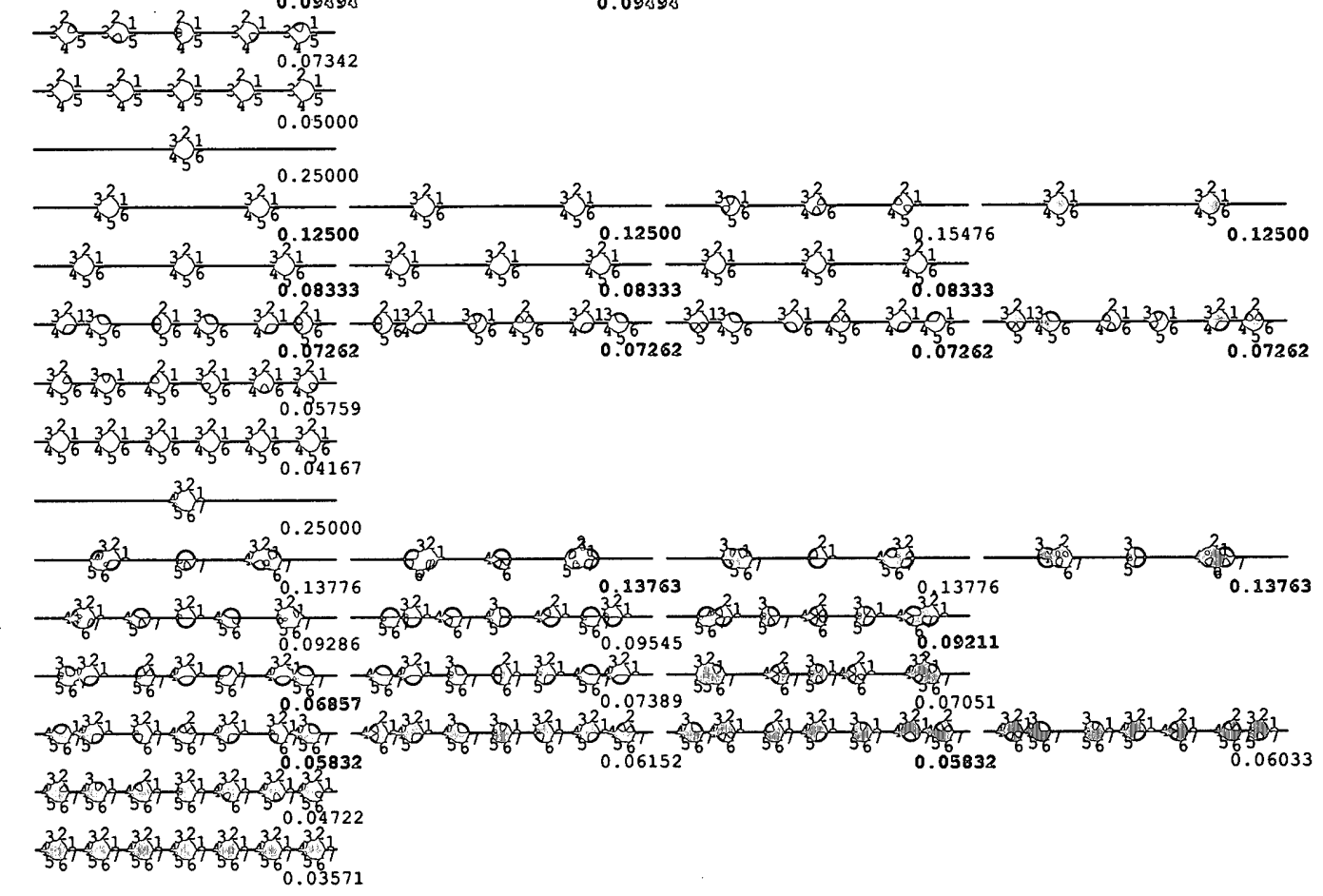

图4 一次元空間における複合サービス施設の最適配置（右下の数字は総利用距離 $T$ 值）

サービスを提供し， $S_{1} \sim S_{4}$ の各サービスはそれぞれそのうち 2 種の

施設により提供されることとなる。このとき，図2に示すように， 同じ $(n, k)$ の組に対してサービスの組合せパターンが 2 通りあるが, このように複数種の組合せパターンがある場合には，それらを a, b, ...を付すことで区別することにする．このようにして $(n, k) に$ 対して 考えられるサービスの組合せパターンを， $n=3,4,5,6,7$ の場合につ いて図 3 に示す。.以下ではこれらに対して最適配置を求める.

（3）最適配置問題の定式化

ある領域 $M$ 内に連続な需要分布が与えられたとき，上述のような サービスの組合せに対し, 総利用距離（平均利用距離でも同じ）を 最小化する連続平面上での minisum タイプの空間複合型施設配置問 題を考える.

各々のサービスに対する利用者（需要）は領域注1)内に均等に分
布しており，それぞれのサービスについてユークリッド距離で最近 僢の施設を選択すると仮定すると，利用者のサービス $\mathrm{S}_{i}$ についての 移動距離の総和は

$$
T_{i}=\int_{x \in M} \min _{j \in F_{i}}\left\|x-x_{j}\right\| \rho_{i}(x) \mathrm{d} x
$$

となる. 但し, $x_{j}$ は施設 $j$ の位置, $\rho_{i}(x)$ は地点 $x$ における需要密 度を表し, サービス $S_{i}$ についての施設利用圈はそのサービスを提供 する施設 $F_{i}$ を母点とする Voronoi 領域となる，これを用いて，全サ ービスに関する総移動距離は

$$
T=\sum_{i=1}^{n} T_{i}
$$

と求められる，以下では， $T$ を最小化する施設配置を求める問題

$$
\min _{\left\{x_{j} \mid j \in \bigcap_{i} F_{i}\right\}} T
$$



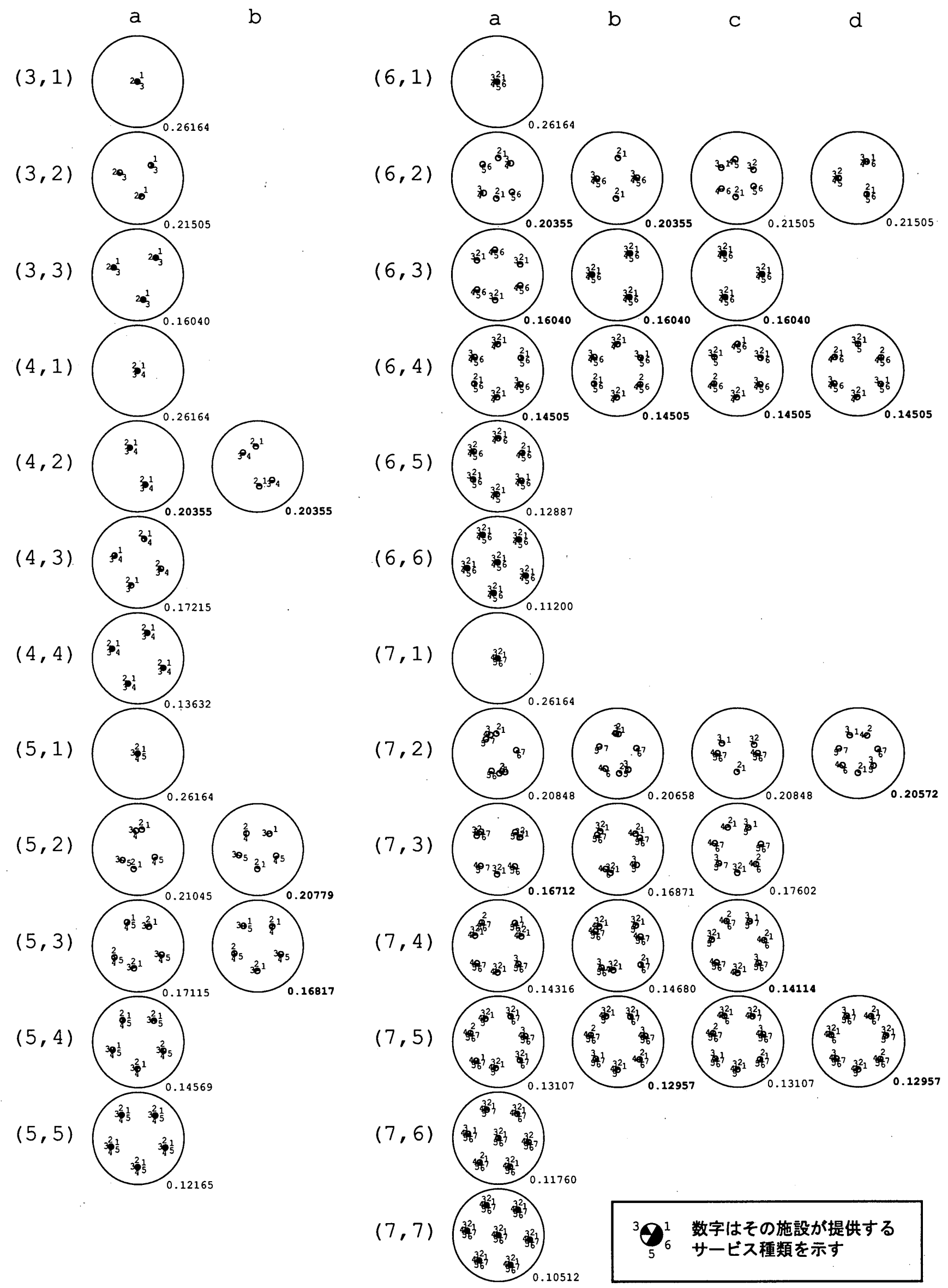

図 5 平面上における複合サービス施設の最適配置（施設数が 1つずつの場合）（右下の数字は総利用距倠 $T$ 值） 
を考え，需要密度が一様な場合について解を求め，その性質を調べ ていくことにする.

\section{3. 線分上における最適施設配置}

（1）解法

領域 $M$ を線分 $[0,1]$ とし，この上に一様な施設需要が分布している ものとする。サービス $\mathrm{S}_{i}$ を提供する施設 $F_{i}$ を座標の小さい順に並べ 替えたものを $x_{(1)}, x_{(2)}, \cdots, x_{\left(n_{i}\right)}$ とすると，

$$
T_{i}=\frac{1}{2} x_{(1)}^{2}+\left(\frac{x_{(2)}-x_{(1)}}{2}\right)^{2}+\cdots+\left(\frac{x_{\left(n_{i}\right)}-x_{\left(n_{i}-1\right)}}{2}\right)^{2}+\frac{1}{2}\left(1-x_{\left(n_{i}\right)}\right)^{2}
$$

と表されるので，施設の並び順が与えられれば $T$ は(2)式より $x_{i}$ を用 いて解析的に表される。ここでは考えられる並び順それぞれについ て, $T$ を導出して連立方程式 $\partial T / \partial x_{i}=0(i=1, \ldots, n)$ を解き，それらの 中で $T$ が最小となる並び順の解をもって最適配置の解を得る。

\section{(2) 最適配置の解}

図 3 のサービスの組合せに対し，各施設が1つずつあるの場合の 最適な施設配置を求めた結果を図 4 に示す，凡例に示すように，施 設の周囲に記された数は提供するサービスを示している．また，い くつかの施設が同じ地点に立地した場合はあたかも一施設のように 示してある。この結果から，以下のことが読みとれる.

(1) $(n, 1),(n, n)$ の場合は，それぞれ一地点への中心集中立地, $n$ 地点の 均等分散立地となる。

(2)サービスの重複のない施設は重なって立地しても良いが, サービ スの重複する施設は互いに離れて立地する。

(3)一般に, $(n, k)(1<k<n)$ の場合は， $(n, n)$ の場合の均等分散立地より も領域中心に片奇った配置となり，施設間距離が一様でないパ夕 ーンが得られる、また，施設のペアが生じる傾向が見られる。

(4) $k$ が $n$ の因数の場合（例えば $(4,2),(6,2),(6,3)$ など）は，複数の施設 が同じ場所に立地し，全サービスを提供する施設が $k$ ケ所に $n / k$ 個ずつ同一地点に重なるように抱き合わせて配置される状態が最 適になる。この場合，施設の位置が重なることにより，あたかも 全てのサービスが統合したような状態になるため, $k$ ヶ所に配置 された施設は均等立地（つまり $(k, k)$ の最適配置）となる。

(5) $k>n / 2$ になると，瀿接施設の提供サービスに必ず重複が生じる ため，(4)のような抱き合わせ配置は見られなくなる.

(6)サービスの組合せパターンが複数種ある場合でも，多くの場合，

配置上の大差は見られない。

このように，互いに対等なサービスの提供を前提とした場合でさ え，全サービスの一部を提供する複合施設の最適配置パターンは均 等配置にはならず，中心集中立地と均等分散立地との中間的なパ夕 ーンとなるということは，直観では想定できない結果である。

\section{4. 有限平面上における最適施設配置}

次にこの問題を実際の都市活動が展開されている二次元平面上で 考え，どのような配置パターンが現れるかを調べることにする.

(1) 解法

有限平面上における(3)式の問題は, 非線形計画問題として数値的 に解くことにより，厳密解ではないが近似解として局所最適解を求
めることができる．降下方向ベクトルは，

$$
\frac{\partial T}{\partial x_{j}}=\sum_{i} \frac{\partial T_{i}}{\partial x_{j}}
$$

であることを利用すれば，各サービスにおける移動距離に関する降 下方向の和として求めることができる，右辺項は鈴木(1990), Suzuki et al. (1991)等と同様に, Iri et al. (1984)の方法を用いて求められる.

（2）施設数が各サービスについて1施設ずつの場合の解

領域 $M$ を直径 1 の円形領域とし，需要密度は一椂とする．図 3 に 示したサービスの組合せについて，各施設が1つずつの場合の解を 図 5 に示す。初期配置は, 線分上の場合と同様, 各サービスの提供 施設の間隔がなるべく均等になるように与えた。○で表された施設の 周囲の数字は提供するサービスを示す。この結果から, 最適配置は 一般に均等分散立地よりも領域の中心に片寄った配置となり，線分 上の最適解の性質と同じ性質を持つことが読みとれる注2!.上の結果 は, 岸本(2000)の多層構造モデルによる検討で明らかにされた、「施 設の複合化により凝集型が優れた配置パターンとなる性質がある」 ことをより体系的に示していると考えることができる.

このように有限平面上でも複合サービス施設の最適配置パターン は一般には均等配置にはならず, サービスの重複度に応じて中心集 中立地と均等分散立地との中間的なパターンが最適配置となること が明確になった。この結果は，複合サービス施設の配置のあり方に 関する基本的知見として重要である。

（3）施設数が各サービスについて複数ある場合の解

これまでの計算例は施設は 1 つずつであった。これに対して，施 設が多数配置される場合はどのようになるであろうか。単一サービ ス施設の場合, 総移動距離を最小にする配置は六角形状の圈域を持 った三角格子状配置パターンとなることが知られている。ここでは 複合サービス施設について施設が多数配置される場合を検討する.

図 6 は，正六角形領域内で $n=7$ とし，各サービスを提供する施設 が 7 施設ずつある場合（計 49 施設）についての最適配置を示したも のである.サービスの組合せに $\mathrm{a}, \mathrm{b}, \cdots$ など複数あるものについては， 総移動距離が最小になるサービスの組合せの最適配置を示している， 施設数が 1 施設の場合には, 線分上のときと同様に均等分散立地 よりも領域の中心に片寄った配置ではあるものの，環状に均等に並 んだパターンが得られており, 均等配置との差異は明確ではなかっ た。図 6 より，多施設の場合，隣接施設間の距離が一様でない状態 が最適となり, 最適配置パターンは均等配置とならない. $k$ が $n$ に近 づくに従って三角格子状配置に近づいていくことがわかる.

このように，複合サービス施設の最適配置パターンは，正確にシ ステマティックな配置とはならず, 中心集中立地と均等分散立地と の中間的なパターンとなることが明らかとなった。

\section{5. 結論と今後の課題}

本論文では，複合サービス施設の最適配置を求め, サービスの組 合せが最適配置に与える影響について，以下のような結論を導いた。 (1) 全サービスの一部を提供する複合サービス施設の最適配置問題 を定式化し，線分空間での解析解を求めた結果，一様需要のもと で互いに対等なサービスの提供を前提とした場合でも，一般に中 心集中立地と均等分散立地の中間的な配置として均等分散立地 
$(7,1)$

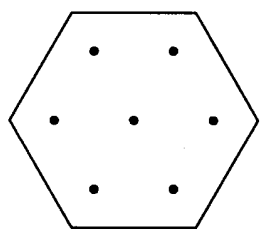

$(7,2)$

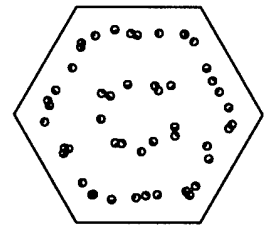

$(7,3)$

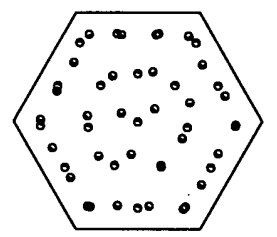

$(7,4)$
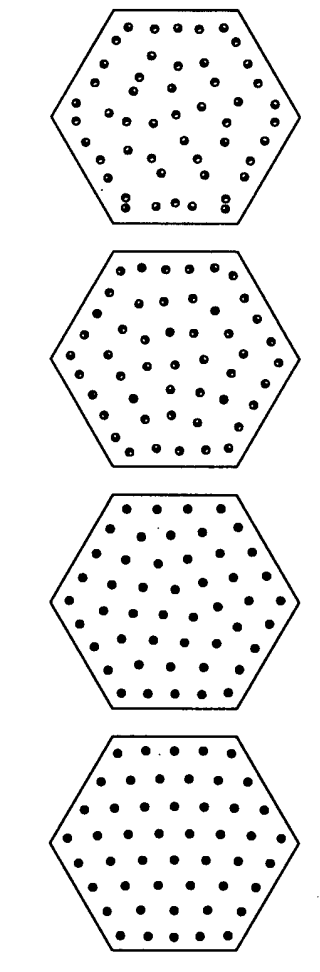

$(7,7)$

$(7,6)$

图 6 平面上における複合サービス施設の最適配置 (施設数が 7 施設ずつの場合)

よりも領域の中心に片奇った一様でないパターンが得られるこ とが明らかとなった。このことは，施設を複合化させる場合，た とえ同等な施設であっても，利用者の平均距離最小化を目的とす るならば对象地域において一様でない配置を検討する必要があ ることを示唆している.

(2) 平面上での局所最適解を数值的に求めた結果, 有限平面上でも一 般に最適配置パターンは均等配置にはならず, サービスの重複度 に応じて中心集中立地と均等分散立地との中間的なパターンが 最適配置となることがわかった，提供サービスの重複度が大きい 場合 $(k>n / 2)$ でも, 正確にシステマティックな配置にはなら ないことが明らかとなった，複合サービス施設の場合，一様でな い配置を検討する必要があることは都市平面上での施設配置に
おいても言えることが明らかとなった。

実際の施設のサービスについて考えると，たとえ同じ種類のサー ビスを行っている施設の間でも，様々な点で施設の提供サービスは 異なったものであるだろう，例えば，図書館では蔵書の種類が全く 同じであるということはない，この場合，両方の図書館に存在する 蔵書に関しては互いに重複するサービスと見なせるし，一方の図書 館にはあるが他方の図書館にはない蔵書は重複しないサービスと見 なすことができる．このように同様の施設群でもサービス内容に差 があるならば，その最適配置は本論文で明らかにされた程度の規則 的配置からのズレがあった方が望ましいことになる．

本論文では，複合化まずありきとしてその最適配置を論じた。し かし，複合化がなぜ有利となるかというメカニズムの部分について は明らかにされていない。この問題を考えるためには, 複合化が有 利となる仕組みを内包したモデルを構築する必要がある，機能複合 や利用複合の場合等の最適配置と併せて, 今後の研究課題としたい. 大変貴重なご意見を頂きました匿名の査読者には，ここに記して 謝意を表します，なお，本論文は文部省科学研究費補助金による研 究成果の一部である。

注

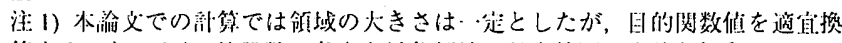
算することにより,施設数の多察を对象領域の設分筑咀の公狭と解积した比較 検得も叮能である。

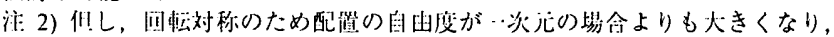

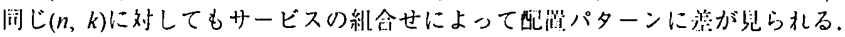

\section{参考文献}

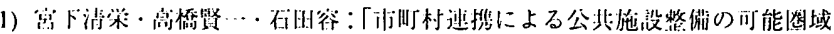

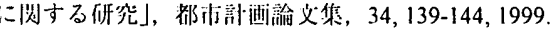

2) Okabe, A., Boots, B. and Sugihara, K.: Spatial Tessellations: Concepts and Applications of Voronoi Diagrams, Chichester: John Wiley, 1992.

3) Okabe, A., Okunuki, K. and Suzuki, T.: "A Computational Method for Optimizing the Hierarchy and Spatial Configuration of Successively Inclusive Facilities on a Continuous Plane," Location Science, 5, 4, 255-268, 1997

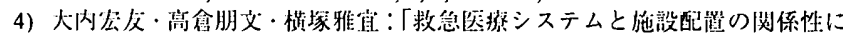

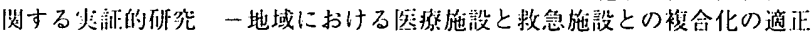

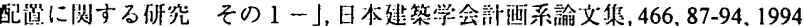

5) Iri, M., Murota, K. and Ohya, T.: "A Fast Voronoi-diagram Algorithm with Applications to Geographical Optimization Problens," in: P.Thoft-Christensen (ed.) l.ecture Notes in Control and Information Science, Vol. 59: System Modelling and Optimization, Proceedings the IFIP Conference on System Modelling and Optimization, Copenhagen, Springer, Berlin, 273-288, 1984

6）岸本達也：「多層構造モデルによる䙓合施設の最邀配䟧」，日本建筑学会計 画系論文集, 529, 233-239, 2000.

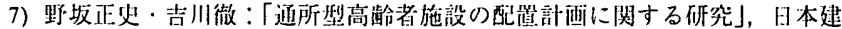
築学会計画系論文集, 525, 201-208, 1999.

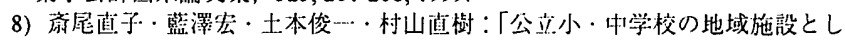
ての機能複合化に関する破究」，日本建築学会計泪系論文集，523，131-138， 1999.

9）位谷宣昭・内田晃・趙世晨・荻島哲 :「ショッピングセンターの栄種の組み 合わせと立地動向に関する研究」，日本建築学会部面系諭文集，531，163-170， 2000.

10)鈴木勉：「利用者の移動費用最小化による施設の银適な建設㮌序と配置」， 都初計画論文集, 23, 61-66, 1988.

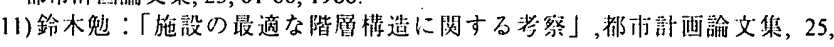
$331-336,1990$

12) Suzuki, T., Okabe, A. and Asami, Y.: "Sequential Location-Allocation of Public Facilities in One- and Two-dimensional Space: Comparison of Several Policies," Mathematical Programming B, 52, 1, 125-146, 1991.

13)谷回沉邦・熊谷昌浐:「教育関連施設における複命施設の没置条件と施設相

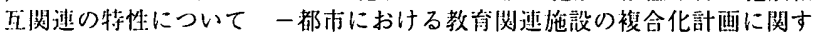
る研究(1)一」, 日本建築学会計画系諭文報告集, 336, 121-131, 1984.

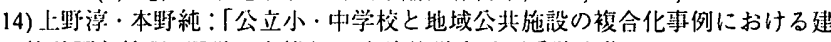

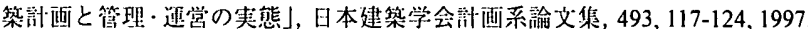

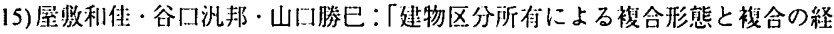

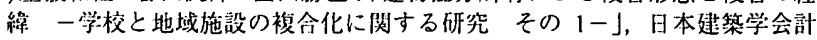
画系論文報告集，452, 65-74, 1993.

（2000年 1 月 6 日原稿受理，2000年 9 月 18 日探用決定） 